\title{
Accounting Education In Crisis
}

Karen F. Turner, Ph.D., CPA, University of Northern Colorado, USA

Ronald O. Reed, Ph.D., CPA, University of Northern Colorado, USA

Janel Greiman, M.T., CPA, University of Northern Colorado, USA

\begin{abstract}
Almost on a daily basis new accounting rules and laws are put into use, creating information that must be known and learned by the accounting faculty and then introduced to and understood by the accounting student. Even with the 150 hours of education now required for CPA licensure, it is impossible to teach and learn all there is to learn. Over the years, changes have been recommended and some adopted into the accounting curriculum; however, the crisis of information overload continues in accounting education.
\end{abstract}

Keywords: Accounting Education in Crisis

\section{INTRODUCTION}

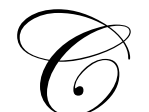

urrently, fifty-four of the fifty-five U.S. jurisdictions require or soon will require 150 hours of education for CPA licensure. Many reasons can be cited for this licensure requirement; however, the most often cited reason is the amount of information that is required for an accountant to be able to adequately serve his or her clients whether the clients are those traditionally served by a CPA firm or whether those served are government agencies, industry, regulatory agencies or education.

This paper summarizes some of that information in the accounting profession and reviews some suggested alternatives for dealing with this information explosion in the institutions of higher learning.

\section{RELATIVELY RECENT CHANGES IN ACCOUNTING EDUCATION}

Traditionally, accounting education has focused on financial accounting, tax, auditing, and cost accounting. Twenty years ago, these traditional courses concentrated on the technical aspects of U.S. Financial Accounting Standards, the Internal Revenue Code, and the Statements of Auditing Standards, with cost accounting being taught on a more conceptual basis. However, the 1980s and 1990s brought huge changes to the accounting industry and, therefore, necessarily to accounting education.

In 1989, the Accounting Education Change Commission (AECC) was formed and backed by American Accounting Association (AAA) and funded by the, then, Big 8 accounting firms. The profession had already recognized the growing complexity of required accounting knowledge and had begun a move towards 150 hours of education for CPA licensure. However, based on input from both academia and the profession, the AECC was formed to deal with "the need to produce accounting graduates who could adapt to change. . The challenge to accounting educators is to maintain the technical accounting competence demanded in graduates, while increasing their understanding of accounting and business so that they can adapt and apply their technical skills to new environments" (Sundem 1999, ch. 1, para. 7).

According to Sundem (1999), the AECC was successful in promoting change in accounting education following the Bedford Committee's recommendations. This Committee's recommendations included lifelong learning based on a broader general education, conceptual understanding of accounting and business matters, ethics, critical thinking, and communications and interpersonal relations (Bedford Commission, 1986). Based on these recommendations, accounting curriculum changed, and academic attitudes changed. For example, the accounting principle courses became more user-oriented rather than preparer-oriented. More emphasis has been put on critical thinking and communications in most accounting programs, as evidenced by assessment goals and objectives of many regionally and AACSB accredited universities. 
Based on these changes and recommendations, accounting education rocked along for the next ten years or so. During this time, the mega-scandals of Waste Management, Xerox, Enron, Adelphia, Worldcom, to name only a very few, led to more accounting regulations and changes to existing regulations, including the creation of the Public Company Accounting Oversight Board (PCAOB) which now is charged with regulating auditors of publically held entities. Its creation was the second time the government has stepped in with a regulatory agency based on accounting scandals. The first was the Securities Exchange Act of 1934 which created the Securities and Exchange Commission. And with these new regulatory agencies and the reaction of the existing regulatory agencies to their "competitors," came more regulations - more rules - more necessary accounting information.

\section{CHANGES IN ACCOUNTING REGULATIONS}

Meanwhile, the U.S. economy has become more global: U.S. companies are expanding into international markets, and international firms are expanding into U.S. markets. Enter the International Accounting Standards Board, founded in 2001, to develop international financial accounting standards and promote their use globally (IASB website, 2011). In 2002, the Financial Accounting Standards Board and the IASB sign the Norwalk Agreement which formalized the agreement between the two Boards to "(a) make their existing financial reporting standards fully compatible as soon as is practicable and (b) to coordinate their future work programs to ensure that one achieved, compatibility is maintained" (FASB website, 2011). At the time of this writing, a number of IASB and FASB standards have been made "compatible," and the two Boards are working on others. However, the acceptance of these joint standards has been slow in the U.S. despite some support from the SEC and their adoption by over 90 countries which have adopted "IFRS" in whole or in part. Additionally, the Uniform CPA Exam given by the American Institute of CPAs began including IFRS questions with its January 2011 exam. More regulationsmore rules - more necessary accounting information.

And more recently, the Blue Ribbon Panel on Private Company Financial Reporting (BRP), a joint commission of the AICPA, Financial Accounting Foundation (FAF) and the National Association of State Boards of Accountancy (NASBA), has recommended the "creation of a new, separate private company standard-setting board with authority to approve GAAP exceptions and modifications under the oversight of the Financial Accounting Foundation" (AICPA 2011) which will promulgate a separate U.S. GAAP for private companies and a separate framework for these same companies. The FAF has not acted upon this recommendation as of this writing and not all those on the BRP were in agreement. For example, NASBA wrote a dissenting opinion that accompanied the BRP's recommendation suggesting that FASB have a chance to address the issues of a private company GAAP. However, the issue of public versus private GAAP is real and to solve it means more regulations-more rulesmore necessary accounting information. And oh, by the way, the IASB also has its own standards for private companies: IFRS for small and medium-sized entities (SMEs).

All in all, the FASB has issued 34 updates to the Codification since its inception-five within the last six months. The Codification began with 168 standards. The IASB has issued 9 IFRSs, 41 IASs, 19 IFRICs and 10 SICs, and one IFRS for SMEs that is 232 pages with 35 sections.

The Governmental Accounting Standards Board has 58 GASBs and any number of GAGAS. The ASB has 121 SASs. The PCAOB has 14 Standards and 52 Interim Standards (AUs) which are partial rules promulgated by the ASB. Additionally, on ethics and independence, the PCAOB has generated 9 rules and adopted 6 partial rules from the AICPA's Code of Professional Conduct. Further, it has adopted 8 Interim Standards on Quality Control adopted from the different sources and 6 Attestation Interim Standards for the ASB.

\section{And these are just for financial accounting and auditing. What about TAX?}

July 2010, the new tax textbooks for the fall semester arrive in the bookstores. In March 2010, the President signed into law the "Health Care Act" which consists of two laws: Patient Protection and Affordable Care Act of 2010, P.L. 111-148 and Health Care and Reconciliation Act of 2010. These two new laws changed, repealed or created any number of tax code sections, affecting many of the rules dealing with health care such as some students once again being covered by their parent's health care plans. These tax laws created an excise tax on medical equipment and tanning beds. Individual, corporate, pass through entities, employment tax and employee benefit 
plans were affected. Additionally, reporting requirement, cellulosic biofuel or black liquor producers' credits, and adoption credits were changed. Indian Tribal Government laws were altered. The economic substance doctrine is now codified. Topics of changes are far too numerous to mention. Thousands of pages of sweeping tax law changes were set to start in 2010, and some of which are to be phased in over the next 10 years.

The textbook is functionally obsolete in individual, corporate, pass-through, and excise tax areas before the shrink wrap is removed.

By the end of this same semester, some legislation is conspicuously absent. Nothing has been done about the Economic Growth and Tax Relief Reconciliation Act of 2001 (EGTRRA) or the Jobs and Growth Tax Relief reconciliation Act of 2003 (JGTRRA) which are both set to expire at the end of the December 2010.

Learning tax law is challenging in a static space. Now, these areas of tax are different from what the book presents. To complicate this issue further, fall final exams are taken in early December. However, December 17, 2010, the Tax Relief, Unemployment Reauthorization and Job Creation Act is signed into law. The tax relief provided by EGTRRA and JGTRRA is extended, albeit modified, through 2012. The estate tax law is reinstated retroactively to January 1,2010 . Individual and corporate taxes have many changes. There are repeals of phaseouts and limitations. The much publicized plans to increase tax for the wealthy are absent. Previous Green Book expectations which predicted anticipated changes such as increasing the long-term capital gain ceiling rate to $20 \%$ is not legislated. The estate provisions now provide a choice for each estate to make. Executors may choose to pay no estate tax and accept a modified carryover basis on the assets transferred by the estate or they may choose to pay estate tax and receive the "step up" in basis on transferred assets. The rules are complex and are slated to expire within a short amount of time. The employee's portion of FICA is decreased from $6.2 \%$ to $4.2 \%$. This is slated to last only through 2011. For the first time, differences exist in employer and employee withholdings for FICA.

That is, the information the fall students learned for their fall exam is now obsolete.

Spring semester starts the middle of January. February 1, 2011, the much anticipated tax update book arrives. That same day, the book's website shows that 68 pages of the text became obsolete during shipping because in January, Expanded Coverdell Accounts are temporarily extended. The American Opportunity Tax Credit is temporarily extended. The expanded student loan interest deduction is temporarily extended. The FICA differences are legislated to last only one year. The chances that on January 1, 2012, employees will have a return to the $6.2 \%$ withholding for FICA are anyone's guess. Property transactions and employee tax changes that are taught in the most basic tax classes are changed.

To complicate matters, parts of the Patient Protection and Affordable Care Act and the Health Care and Education Reconciliation Act of 2010 are being tested in the courts. The courts find that parts of the 2010 acts are unconstitutional, so legislation to modify parts of the acts is being drafted. There is much lobbying to change the reporting requirements provided by the new legislation.

By 2013 graduation, most of the phased-in changes will have taken effect. The extension acts will have expired December $31^{\text {st }}, 2012$. And undoubtedly, the tax laws will have been added to, changed and some will have expired or been superseded.

Will their tax education be out of date before the ink dries on their diplomas or they sit for the tax section of the CPA exam?

\section{SOLUTIONS TO THE CRISIS}

As discussed above, the accounting profession and the accounting faculty have been aware of the need to improve the accounting curriculum for a number of years. The Bedford Commission (1986) and the National Commission on Fraudulent Financial Reporting (Treadway Commission) (1987) coming from different points of view both made some specific suggests about where accounting education should be heading. However, both agreed that accounting students should be taught critical thinking and communication skills and ethics. Based on 
these recommendations, many accounting programs adjusted their curriculums to include more conceptual training, more emphasis on research and communications, and more discussion of ethics, values and the professional codes of conduct.

More recently the International Accounting Education Standards Board has issued an exposure draft, Entry Requirements to Professional Accounting Education, Exposure Draft, which calls for an educational curriculum that builds on a general education and includes technical accounting knowledge along with professional skills and values, ethics and attitudes in order to protect the public interest (IFAC, 2011).

Earlier, the Department of the Treasury formed the Advisory Committee on the Auditing Profession (ACAP). This committee's charge was "to examine comprehensively the condition and future of the auditing profession, with emphasis on the sustainability of a strong and vibrant profession" (ACAP Report, 2008, p. II:1). In its report it made several recommendations concerning the curriculum for and structure of accounting education. Its first recommendation concerning higher education was for accounting programs to implement a "market-driven, dynamic curricula" which would enable new auditors to perform better audits. (ACAP, 2008, p. VI:2). Within this recommendation was a call for the AICPA to continually update the Uniform CPA Exam, including coverage of professional and ethical standards, fraud, risk management, valuation and a broader array of business topics. The Committee felt that a current exam would encourage an updated curriculum.

The AICPA took this recommendation to heart. The exam now includes a section on Business Environment and Concepts (BEC), and the Financial Accounting and Reporting section (FAR) includes questions about IFRS.

Several other recommendations included ways to keep faculty more current including more interaction between academics and accounting professionals such as cross-sabbaticals and incentives for funding by the profession of accounting faculty and faculty research in order to develop better and more effective and current teaching materials. To their credit, many of the firms are now involved with developing and sharing teaching materials, and more faculty are becoming interested in faculty internships with the firms and in industry.

ACAP's last recommendation concerning higher education was to call for a joint commission of the AICPA and AAA "to provide a timely study of the possible future structure of higher education for the accounting profession" (ACAP, 2008, p. VI:25). The report suggests that this commission should "consider the potential role of a post graduate professional school model to enhance the quality and sustainability of a vibrant accounting and auditing profession" (ACAP, 2008, p. VI:26). Such a commission has been formed with a large membership from all walks of accounting life including academia, the auditing and tax profession, government, internal auditing, industry, regulatory agencies, and state societies of CPAs. The Blue Ribbon Panel held its first meeting in October 2008, shortly after the ACPA report was issued and has met continuously over the past two and one half years. According to a recent interview with Bruce Behn, chair of the Panel, a preliminary report should be issued by the first of 2013. (Bonner, 2011).

Although this sounds like a radical solution, it's not a new idea. For example, according to Sundem (1999), pharmacy schools tried a five year structure similar to that of the accounting profession's 150-hour requirement but found that this structure was inadequate and went to stand-alone pharmacy schools as did law schools almost a century ago. Now law school curricula focuses on teaching students conceptually how to think about the law, rather than to memorize the law.

In 1989, the AECC was formed to deal with "the need to produce accounting graduates who could adapt to change" (Sundem 1999, ch. 1, para. 7). Whatever structure or curriculum that we as accounting professionals embrace, it must meet this need. For undergraduate students, teaching, for example, the basic tax legal process may be more important than assuring that they learn specific rules. This strategy may also be a transition to introduce basic research skills and encourage students to be aware of current events.

Rather than merely running to keep up with the ever increasing pace of changes, accounting education can embrace this phenomenon to enrich the educational experience and better prepare our students to acclimate into their 
professional careers. Today's crisis may be tomorrow's normal pace given the ever increasing normalcy of change. Higher education should provide the students with an environment to become proficient in using whatever tools at their disposal so that they may be confident in finding answers to new rules and laws and to question all rules to ensure that each meets the conceptual framework within which these same rules and laws were created.

Our future professional and leaders will be stratified by their ability to adapt and to incorporate this new mode of operation as second nature.

\section{AUTHOR INFORMATION}

Karen Turner has over 30 years of teaching experience in financial accounting, audit, and communications. She received her Ph.D. in accounting from the University of Texas at Arlington and her M.A. in English from Texas A\&M University. E-mail: karen.turner@unco.edu

Ronald Reed is a Professor of Accounting at the University of Northern Colorado (UNC) and received his Ph.D. in accounting from Texas Tech University. Ron primarily teaches in the auditing, financial, and managerial accounting areas of accounting and has numerous publications in these areas. He is a member of the AAA, AICPA, CSCPA, and FEI and has held Board positions in the CSCPA and FEI. E-mail: ronald.reed@unco.edu

Janel Greiman is a lecturer at the Monfort College of Business at the University of Northern Colorado. She teaches accounting with an emphasis in taxation. She teaches tax at the undergraduate level as well as in the Master of Accountancy program. Ms. Greiman earned her Mater of Taxation at the Strum College of Law at the University of Denver. She is a CPA in Colorado with recent experience practicing in taxation. She is a Member of the AICPA, the CSCPA and the tax section of the CSCPA. E-mail: janel.greiman@unco.edu

\section{REFERENCES}

1. American Accounting Association (AAA), Committee on the Future Structure, Content, and Scope of Accounting Education (The Bedford Committee). 1986. Future Accounting Education: Preparing for the Expanding Profession. http://aaahq.org?AECC/future/cover.htm

2. American Institute of Certified Public Accountants (AICPA), April 28, 2011. Letter to Financial Leaders from Carol Scott. http://www.aicpa.org/InterestAreas/BusinessIndustryAndGovernment/NewsAndPublications/Pages/BRP_S ubmits_Recommendations_to_FAF.aspx

3. Bonner, P, 2011. Pathways commission forges ahead. Journal of Accountancy, vol. 211, issue 5, (May): $30-31$.

4. Department of the Treasury (DOT), Advisory Committee on the Auditing Profession. 2008. Final Report of the Advisory Committee on the Auditing Profession to the U.S. Department of the Treasury. Washington, D.C.

5. 2011. General Explanation of the Administration's Fiscal Year 2012 Revenue Proposals (Greenbook). Washington, D.C.

6. Economic Growth and Tax Relief Reconciliation Act of 2001, P.L. 107-16

7. Financial Accounting Standards Board (FASB). Memorandum of Understanding, "The Norwalk Agreement" 2002. http://www.fasb.org/news/memorandum.pdf

8. International Accounting Standards Board (IASB). 2011. The Organisation, About the IRFS Foundation and the IASB. http://www.ifrs.org/The+organisation/IASCF+and+IASB.htm

9. International Federation of Accountants (IFAC). 2011. IES, Entry Requirements to Professional Accounting Education, Exposure Draft. New York, NY.

10. Patient Protection and Affordable Care Act of 2010, P.L. 111-148 and Health Care and Reconciliation Act of 2010, P.L. 111-152

11. Sundem, G. L. 1999The Accounting Education Change Commission: Its History and Impact. American Accounting Association, Sarasota, FL.

12. Tax Relief, Unemployment Insurance Reauthorization and Job Creation Act of 2010, P.L. 111-312 
NOTES 